\title{
Seasonal changes in glacial polynya activity inferred from Weddell Sea varves
}

\author{
D. Sprenk ${ }^{1}$, M. E. Weber ${ }^{1}$, G. Kuhn ${ }^{2}$, V. Wennrich ${ }^{1}$, T. Hartmann ${ }^{1}$, and K. Seelos ${ }^{3}$ \\ ${ }^{1}$ University of Cologne, Institute of Geology and Mineralogy, Cologne, Germany \\ ${ }^{2}$ Alfred-Wegener-Institut Helmholtz-Zentrum für Polar- und Meeresforschung, Bremerhaven, Germany \\ ${ }^{3}$ Johannes Gutenberg University Mainz, Institute of Geosciences, Mainz, Germany \\ Correspondence to: D. Sprenk (danielasprenk@gmail.com)
}

Received: 15 August 2013 - Published in Clim. Past Discuss.: 6 September 2013

Revised: 9 May 2014 - Accepted: 12 May 2014 - Published: 25 June 2014

\begin{abstract}
The Weddell Sea and the associated FilchnerRønne Ice Shelf constitute key regions for global bottomwater production today. However, little is known about bottom-water production under different climate and icesheet conditions. Therefore, we studied core PS1795, which consists primarily of fine-grained siliciclastic varves that were deposited on contourite ridges in the southeastern Weddell Sea during the Last Glacial Maximum (LGM). We conducted high-resolution X-ray fluorescence (XRF) analysis and grain-size measurements with the RADIUS tool (Seelos and Sirocko, 2005) using thin sections to characterize the two seasonal components of the varves at sub-mm resolution to distinguish the seasonal components of the varves.

Bright layers contain coarser grains that can mainly be identified as quartz in the medium-to-coarse silt grain size. They also contain higher amounts of $\mathrm{Si}, \mathrm{Zr}, \mathrm{Ca}$, and $\mathrm{Sr}$, as well as more ice-rafted debris (IRD). Dark layers, on the other hand, contain finer particles such as mica and clay minerals from the chlorite and illite groups. In addition, $\mathrm{Fe}, \mathrm{Ti}, \mathrm{Rb}$, and $\mathrm{K}$ are elevated. Based on these findings as well as on previous analyses on neighbouring cores, we propose a model of enhanced thermohaline convection in front of a grounded ice sheet that is supported by seasonally variable coastal polynya activity during the LGM. Accordingly, katabatic (i.e. offshore blowing) winds removed sea ice from the ice edge, leading to coastal polynya formation. We suggest that glacial processes were similar to today with stronger katabatic winds and enhanced coastal polynya activity during the winter season. Under these conditions, lighter coarser-grained layers are likely glacial winter deposits, when brine rejection was increased, leading to
\end{abstract}

enhanced bottom-water formation and increased sediment transport. Vice versa, darker finer-grained layers were then deposited during less windier season, mainly during summer, when coastal polynya activity was likely reduced.

\section{Introduction}

The Weddell Sea is a key region for Earth's climate variability because it influences global thermohaline circulation (Seidov et al., 2001; Rahmstorf, 2002) as one of the major sites of deep- and bottom-water formation (Huhn et al., 2008). The present-day bottom-water formation requires flow and mixing of water masses underneath the Filchner-Rønne Ice Shelf (Fig. 1) and brine release within polynyas on the southern Weddell Sea shelf to form cold and dense water masses that can flow across the shelf and into the deep Weddell Basin.

However, little is known about glacial bottom-water production, although Antarctica may have acted as a major supplier of deep water, i.e. Antarctic Bottom Water (AABW) during stadials (Shin et al., 2003), when North Atlantic Deep Water (NADW) production was sluggish or even terminated (e.g. Stocker and Johnson, 2003; Knutti et al., 2004). Glacial times did not involve major floating ice shelves (e.g. Hillenbrand et al., 2012). Specifically during the Last Glacial Maximum (LGM) from 26.5 to 19 ka before present (BP) (Clark et al., 2009), most ice sheets were grounded and had advanced close to or even reached the shelf edge. Also, for the Weddell Sea, the LGM ice sheet advanced to at least within $40 \mathrm{~km}$ (Larter et al., 2012) of the shelf edge and most likely reached it (Elverhøi, 1984; Weber et al., 2011; Hillenbrand 


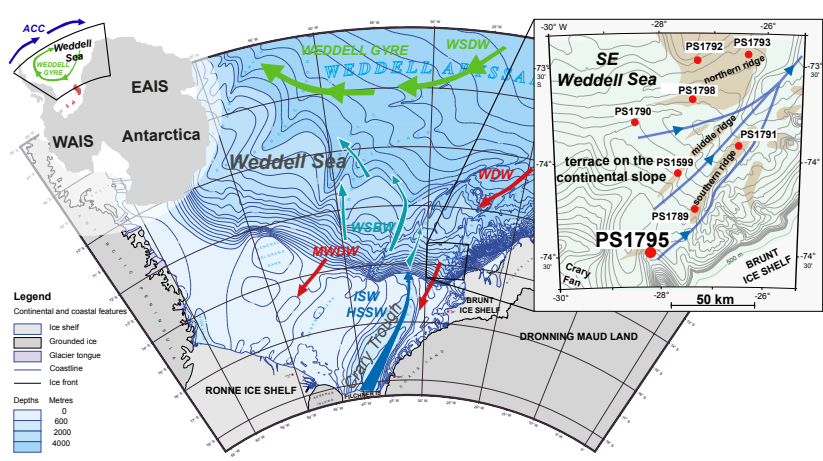

Figure 1. Left: overview map showing whole Antarctica with the West (WAIS) and East (EAIS) Antarctic Ice Sheets as well as the Antarctic Peninsula. The Weddell Sea (black square) is located in the southernmost part of Atlantic sector of the Southern Ocean. Additionally, the clockwise flowing Antarctic Circumpolar Current (ACC) and the Weddell Gyre (green arrows) are highlighted. The map in the centre shows a bathymetric chart of the Weddell Sea (Alfred Wegener Institute for Polar and Marine Research BCWS $1: 3000$ 000; Bremerhaven, 1997). Present-day flow direction of important water masses, i.e. high salinity shelf water (HSSW), ice shelf water (ISW), Weddell Sea Bottom Water (WSBW), warm deep water (WDW) and the through heat loss modified WDW (MWDW) are also indicated (further information see Sect. 2.2). The core site area (black box) is located in the southeastern Weddell Sea close to the Brunt Ice Shelf. The small map on the right is a bathymetric map focusing on the southeastern Weddell Sea (modified after Weber et al., 1994), highlighting the Polarstern (PS) core sites referred to in this study (red dots). The core sites are located on ridges on a terrace of the continental slope. Southeast of each ridge (brown colour) runs a channel. During the LGM the thermohaline current (blue lines) was flowing towards the NE in the channels. Due to the Coriolis force most of the transported sediment is deposited NW of each channel.

et al., 2012; Larter et al., 2012). Therefore, glacial bottomwater production must have been very different than today because ice shelf cavities, which are required to cool highsalinity shelf water (HSSW) today and produce ice-shelf water (ISW), did not exist (Gales et al., 2012) back then. Here, we will provide a conceptual model of glacial brine rejection in coastal polynyas that led to intense thermohaline convection in front of a grounded ice sheet as a possible model for glacial bottom-water production.

During the LGM and the last glacial transition, the East Antarctic Ice Sheet had advanced to the shelf break and coastal polynyas were active above the continental slope (Smith et al., 2010). This led to brine rejection and the formation of a high-salinity water mass (Weber et al., 2011). This dense water mass reworked sediment and drained into the channels of the channel-ridge systems located on a terrace of the continental slope in the southeastern Weddell Sea (Fig. 1) (Weber et al., 1994, 2010). The sedimentary material was deposited on the northwestern shoulder of each channel due to Coriolis force, thereby forming natural levees (Michels et al., 2002). Final retreat of the East Antarctic Ice Sheet was around $16 \mathrm{ka}$, marked by a transition from laminated to bioturbated sediment as documented in a number of core sites from the channel-ridge systems (Weber et al., 2011).

Earlier studies (e.g. Weber et al., 1994, 2010, 2011) have shown that the deposits of the ridges are mostly laminated terrigenous sediment and provided evidence that the laminations represent true varves formed by seasonal variations in thermohaline convection during the LGM. To obtain detailed information on the internal structure of the varves on a seasonal scale, we investigated gravity core PS1795 from the same channel-ridge systems and analysed sediment physical properties. For the first time ever, we present thin sections and consequently high-resolution images of the varved sediment from the channel-ridge system in the SE Weddell Sea. Furthermore, we include high-resolution X-ray fluorescence (XRF) analysis and grain-size measurements with the RADIUS tool (Seelos and Sirocko, 2005) using thin sections to characterize the two seasonal components of the varves at sub-mm resolution and to distinguish the seasonal components of the varves. Accordingly, this study provides novel insight into the composition of the varved sediment and the elemental and mineral composition changes between the lighter, coarser-grained layers and the darker, finer-grained layers.

\section{Study area and regional oceanography}

We study gravity core PS1795 originating from the southeastern Weddell Sea, which was retrieved with $\mathrm{R} / \mathrm{V} \mathrm{Po}$ larstern (PS) in 1990 (Fig. 1). The core site is located in a channel-ridge system on a terrace of the continental slope in $1884 \mathrm{~m}$ water depth. Each ridge is up to $300 \mathrm{~m}$ high and up to $100 \mathrm{~km}$ long and runs parallel, on the northwestern side of a channel (e.g. Kuhn and Weber, 1993; Weber et al., 1994).

The Weddell Sea is the southernmost part of the Atlantic sector of the Southern Ocean. The South Scotia Ridge marks the northern boundary and in the east it is limited by the Coats Land and Dronning Maud Land, where smaller ice shelves like the Brunt and Riiser-Larsen Ice Shelf are located offshore (Fig. 1). The southern Weddell Sea is covered by the Filchner-Rønne Ice Shelf. In the west the Antarctic Peninsula borders the Weddell Sea.

About $60 \%$ (Orsi et al., 1999) to $70 \%$ (Carmack and Foster, 1977) of the Antarctic Bottom Water (AABW) originates from the Weddell Sea, where Weddell Sea Bottom Water (WSBW) is produced (Foldvik et al., 2004; Huhn et al., 2008). Maldonado et al. (2005) even argued that $80 \%$ of AABW is produced in the Weddell Sea.

Cyclonic movement of all water masses within the Weddell Gyre dominates the Weddell Sea circulation (Fig. 1). Relatively warm circumpolar deep water (CDW) is transported by the Weddell Gyre from the Antarctic Circumpolar Current (ACC) southwards along the eastern boundary into 
the Weddell Sea and mixes with cold surface waters generating warm deep water (WDW) (e.g. Orsi et al., 1993; Gordon et al., 2010). Through heat loss and mixing primarily during winter with winter water (WW) when flowing further to the west along the continental margin, WDW becomes modified warm deep water (MWDW). MWDW intrudes onto the shelf and mixes with the ISW to produce WSBW (Foldvik et al., 1985). HSSW is generated during sea-ice production by brine rejection (Foldvik et al., 2004; Petty et al., 2013) and supercooled by circulation under the ice shelf, thereby creating dense and cold ice-shelf water (ISW; Nicholls et al., 2009). Passive tracer experiments also point to the FilchnerRønne Ice Shelf as the main location for bottom-water production (Beckmann et al., 1999).

Bottom-water drainage is across the over-deepened Filchner Trough along the south-north running channel-ridge systems into the Weddell Basin (Fig. 1). There, it is deflected to the west due to Coriolis force and flows clockwise along the continental slope within the Weddell Gyre (Foldvik, 1986). However, a current-meter mooring (AWI-213) in the northeastern prolongation of the channel-ridge systems shows a near-bottom flow underneath the Weddell Gyre with a predominant northeastern direction (Weber et al., 1994).

\section{Methods}

Gravity core PS1795 was opened and split into archive and working halves at the laboratory of the Alfred Wegener Institute (Bremerhaven) in 2011. All sampling was accomplished on working halves, whereas sediment physical properties were measured non-destructively at $1 \mathrm{~cm}$ increments on full round core sections and archive halves. We used the GEOTEK Multi-Sensor-Core Logger (MSCL; method see Weber et al., 1997) for determining wet-bulk density, compression wave velocity as well as magnetic susceptibility. For magnetic susceptibility measurements a Bartington point sensor (MS2F) was used and the data was volume-corrected. Also L*, a*, and $\mathrm{b}^{*}$ colour components (Weber, 1998) were measured, using a Minolta spectrophotometer CM-2002. L* gives information about the sediment lightness, colour $\mathrm{a}^{*}$ reflects the amount of green-red, and colour $b^{*}$ is the blueyellow component.

Water content was estimated on sediment samples every $5 \mathrm{~cm}$ by freeze-drying. Information about the geochemical composition was gained by analysing bulk samples with an LECO element analyser. Contents of total carbon (TC), inorganic carbon (TIC), and organic carbon (TOC; TIC subtracted from TC), as well as total nitrogen (TN) and total sulfur (TS) were measured. We also determined biogenic opal contents by leaching with $1 \mathrm{M} \mathrm{NaOH}$-solution according to the method of Müller and Schneider (1993). All resulting bulk data have been corrected for the sea salt content of the pore fluid (35\% , i.e. the salinity of seawater).
To analyse sediment fabric, we cut out $1 \mathrm{~cm}$ thick, $10 \mathrm{~cm}$ wide, and $25 \mathrm{~cm}$ long plates from the centre of each core using a double-bladed saw. The plates were exposed for 3 to 5 min to a HP 43855 X-Ray System. After scanning the negatives at 300 dots per inch (dpi) resolution, we adjusted brightness and contrast to enable a better distinction of dark and bright layers, which are only a few millimetres thick. Additionally we counted all grains $>1$ and $>2 \mathrm{~mm}$ in diameter, reflecting ice-rafted debris (IRD). To do so, we used the scanned $\mathrm{X}$-radiographs and placed a semi-transparent $1 \times 1 \mathrm{~mm}$ grid onto it; for further information on the method see Grobe (1987).

To obtain information on the distribution of chemical elements, we measured the sediment cores non-destructively at $1 \mathrm{~cm}$ resolution using an Avaatech XRF core scanner (Jansen et al., 1998) at the Alfred Wegener Institute in Bremerhaven. The theoretical detection limits of the XRF-scanner is given in Richter et al. (2006). For high-resolution element analysis, XRF-scanning was carried out every $0.2 \mathrm{~mm}$ on three consecutive split sediment core sections $(197-499 \mathrm{~cm})$ of PS1795 using a $3.0 \mathrm{~kW}$ molybdenum tube. For these measurements, the ITRAX XRF-scanner (Cox Analytical, Sweden), a multifunction instrument for non-destructive optical, radiographic and chemical elemental sediment core analyses (Croudace et al., 2006), was used at the Cologne University laboratory. All XRF-scanning results are presented as non-calibrated raw counts. The theoretical limits of detection of the ITRAX XRF-scanner are detailed in Croudace et al. (2006). We also used the ITRAX scanner equipped with a $1.9 \mathrm{~kW}$ chromium tube, to produce X-radiographs of the archive halves.

For accelerator mass spectrometry (AMS) radiocarbon dating we used sediment slices up to $25 \mathrm{~cm}$ thick and studied the sand fraction under the microscope to collect enough well-preserved carbonate shell material from planktonic foraminifera Neogloboquadrina pachyderma (sinistral) for six AMS ${ }^{14} \mathrm{C}$ analyses (Table 1). Beforehand, $\mathrm{H}_{2} \mathrm{O}_{2}$ was added to each sample to remove the organic material. All measurements were conducted at the ETH laboratory of Ion Beam Physics in Zurich. ${ }^{14} \mathrm{C}$ ages were corrected for the marine reservoir effect $(1.215 \pm 30$ years; see Weber et al., 2011), based on age dating of carbonate shell material from a living bryozoa from neighbouring Site PS1418-1 (Melles, 1991). Three samples have less than or around $0.3 \mathrm{mgC}$, which is close to the detection limit of radiocarbon dating possible at ETH Zurich. Clam version 2.1 (Blaauw, 2010) and Marine09 calibration curve (Reimer et al., 2009) were applied to calibrate the ${ }^{14} \mathrm{C}$ data of PS1795 and calculate calendar ages (Table 1). We used a cubic spline age-depth model with the weighted average of 10000 iterations at the $95 \%$ confidence level.

We also produced two overlapping thin sections (PS1795: $354.6-373.2 \mathrm{~cm} ; 371.5-381.2 \mathrm{~cm})$ for detailed analysis of individual layers. Therefore, aluminium boxes were pressed into the sediment and then sliced with a wire. After carefully removing the sediment slabs from the core half, 
Table 1. Accelerator mass spectrometry (AMS) ${ }^{14} \mathrm{C}$ ages and uncertainties of sediment core PS1795, measured on planktonic foraminifera Neogloboquadrina pachyderma shells at the ETH laboratory of Ion Beam Physics in Zurich. Clam 2.1 (Blaauw, 2010) and the Marine09 calibration curve (Reimer et al., 2009) were used to calculate calendar years before present (cal yr BP).

\begin{tabular}{lrrrrrr}
\hline $\begin{array}{l}\text { Laboratory } \\
\text { code }\end{array}$ & $\begin{array}{r}\text { Sample } \\
\text { depth }(\mathrm{cm})\end{array}$ & $\begin{array}{r}\text { Amount } \\
\mathrm{C}(\mathrm{mg})\end{array}$ & $\begin{array}{r}\text { Uncalibrated }{ }^{14} \text { C age } \\
(\mathrm{yr} \text { BP }) \pm \text { error }\end{array}$ & $\begin{array}{r}\text { Age min } \\
(\text { cal yr BP })\end{array}$ & $\begin{array}{r}\text { Age max } \\
(\text { cal yr BP })\end{array}$ & $\begin{array}{r}\text { Probab. } \\
(\%)\end{array}$ \\
\hline ETH-48371 & $210-215$ & $0,23^{*}$ & $15947 \pm 77$ & 17087 & 17797 & 95 \\
ETH-48372 & $390-415$ & $0,38^{*}$ & $22211 \pm 86$ & 24304 & 24946 & 95 \\
ETH-48373 & 450 & 0,87 & $20501 \pm 60$ & 22221 & 22678 & 83.9 \\
ETH-48373 & 450 & 0,87 & $20501 \pm 60$ & 22764 & 22950 & 8 \\
ETH-48373 & 450 & 0,87 & $20501 \pm 60$ & 23140 & 23229 & 3.1 \\
ETH-48374 & $655-680$ & $0,31^{*}$ & $21912 \pm 90$ & 23903 & 24474 & 95 \\
ETH-48375 & $775-795$ & 0,42 & $21546 \pm 80$ & 23437 & 24170 & 95 \\
ETH-48376 & $865-880$ & 0,54 & $21643 \pm 77$ & 23558 & 24289 & 95 \\
\hline
\end{tabular}

* indicates samples close to the detection limit of radiocarbon dating possible at ETH Zurich.

samples were immediately flash-frozen in liquid nitrogen and then freeze-dried. Slabs were then embedded in epoxy resin under vacuum and cured afterwards. For more details on the method see Cook et al. (2009) and Francus and Asikainen (2001). To obtain thin sections, the dried epoxyimpregnated sediment slabs were cut, ground and polished to a thickness of only a few millimetres. To investigate elemental composition changes, we scanned the sediment slabs prepared for thin sections using the ITRAX system at the University of Cologne at $0.2 \mathrm{~mm}$ resolution as well as scanned the sediment slabs with a flatbed scanner for negative transparency scanning (Fig. 4). Additionally, three archive halves were scanned for XRF at high resolution. Due to the facts that the varves are not exactly horizontally orientated and the radiographs were taken from a different part of the sediment than the XRF scanner data, both data sets do not reflect the same position in the sediment at the same depth. Therefore, we shifted the complete XRF data curves a few millimetres (Fig. 5) in order to align them.

Additionally, we applied the RADIUS tool that provides rapid particle analysis of digital images by ultra-highresolution scanning of thin sections (Seelos and Sirocko, 2005). This tool uses the commercial image processing software analySIS (Soft Imaging System GmbH), controlled by three macro-scripts (Seelos, 2004). Thin sections were therefore scanned on a fully automatic polarization microscope in combination with a digital microscope camera at the University of Mainz. The scripts derive mineral-specific particlesize distributions that cover grain sizes from medium silt to coarse sand. The RADIUS tool was used on the thin sections (PS1795: $354.6-373.2 \mathrm{~cm} ; 371.5-381.2 \mathrm{~cm}$ ) at $100 \mu \mathrm{m}$ resolution.

For automatic layer recognition and counting we used the BMPix and PEAK tool (Weber et al., 2010). First, grey values were extracted from the scanned X-radiographs using the BMPix tool. Then, the PEAK tool was used to count every maximum (bright layers), every minimum (dark lay- ers), or every transition of the grey scale curve. For more precise counting results we manually examined and revised all counting results generated by the PEAK tool.

\section{Results}

\subsection{Sediment physical data}

The $8.99 \mathrm{~m}$ long gravity core PS $1795\left(74^{\circ} 30^{\prime} \mathrm{S}, 28^{\circ} 11^{\prime} \mathrm{W}\right.$, $1884 \mathrm{~m}$ water depth) is located southwest of the southern sediment ridge (Fig. 1). Sediments are relatively homogeneous grey to brown (Fig. 2a). Only the uppermost $23 \mathrm{~cm}$ are yellow to orange-brown due to oxidation. Analyses of the coarse grain fraction $(>63 \mu \mathrm{m})$ of PS1795 at $5 \mathrm{~cm}$ increments show that the main components of the coarse grains are quartz ( $80 \%$ on average) and feldspars, whereas biotite and hornblende make up 3-5\%. Overall, maxima in magnetic susceptibility (Fig. 2c) correlate with high IRD counts (Fig. 2b).

The first 2.15 metres of the sediment core are bioturbated with varying amount of IRD (Fig. 2). From $2.15 \mathrm{~m}$ to the bottom of the core at $8.99 \mathrm{~m}$, sediment is mostly laminated, consisting of alternating lighter coarser-grained and darker finer-grained layers, each only up to a few millimetres thick. Laminated sediment consists mainly of terrigenous material with only $2-6 \%$ biogenic opal, less than $0.2 \%$ TIC/TOC, and about $0.04 \% \mathrm{TN}$. Given that these data were retrieved every $5 \mathrm{~cm}$, the resolution is too low to investigate seasonal changes. Wet-bulk density varies only slightly from 1.8 to $2.0 \mathrm{~g} \mathrm{~cm}^{-3}$. IRD content shows relatively strong fluctuations in the laminated sediment and varies between 0 and 18 grains $\mathrm{cm}^{-2}$ (Fig. 2).

\subsection{Chronology}

Three of the ${ }^{14} \mathrm{C}$ samples over about $2 \mathrm{~m}$ are statistically indistinguishable. Nonetheless, the error range of ${ }^{14} \mathrm{C}$ age of 


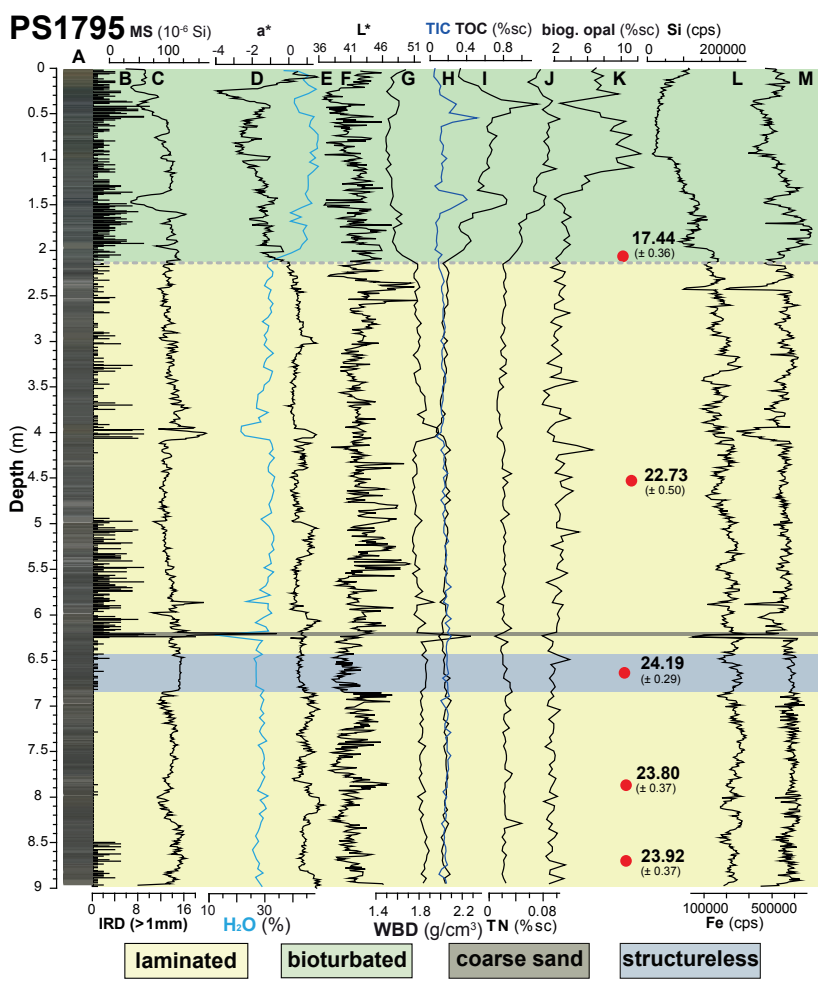

Figure 2. Sediment physical data from sediment core PS1795: A shows the red/green/blue (RGB) colour pattern; B shows the amounts of grains $>1 \mathrm{~mm}$, representing ice-rafted debris (IRD; method see Grobe, 1987); C is magnetic susceptibility (MS) record; $\mathrm{D}$ is colour $\mathrm{a}^{*}$ (green-red component); $\mathrm{E}$ shows the water content of the sediment; F gives lightness ( $\left.L^{*}\right)$; $G$ is wet-bulk density (WBD); $\mathrm{H}$ to $\mathrm{K}$ are sea-salt-corrected (sc) total organic and inorganic carbon (TIC/TOC), biogenic opal, and total nitrogen (TN); $\mathrm{L}$ and $\mathrm{M}$ show chemical elements silicon $(\mathrm{Si})$, and iron $(\mathrm{Fe})$ determined with an X-ray fluorescence scanner. $\mathrm{AMS}^{14} \mathrm{C}$ ages (marked with red dots) measured on planktonic foraminifera Neogloboquadrina pachyderma are given in ka cal before present. The grey line at $2.15 \mathrm{~m}$ depth marks a possible hiatus (see Sect. 4.2).

$24.19 \pm 0.29 \mathrm{ka}$ at $6.68 \mathrm{~m}$ depth lies within the age range of the age-depth models and is possibly caused by high linear sedimentation rates of about $1.1-1.6 \mathrm{~m} \mathrm{kyr}^{-1}$ (Fig. 6). We constructed two different age-depth models for the sediment core PS1795. The first age model is for undisturbed sediments and relies only on the ${ }^{14} \mathrm{C}$ ages, whereas the second includes a hiatus at a core depth of about $2.15 \mathrm{~m}$. The Xradiograph highlights an erosive contact between laminated and bioturbated sediment at $2.15 \mathrm{~m}$ (Fig. 2) and also the varve counting results lead to the assumption that sedimentation is disturbed at the base of the bioturbated section. However, it is not possible to count the varves accurately between 2.15 and $2.57 \mathrm{~m}$ due to the low quality of the X-radiographs. Nonetheless, based on the visually detectable faint lamination, the material can be considered varved. Using an estimated LSR of approximately $1.1-1.6 \mathrm{~m} \mathrm{kyr}^{-1}$ the varved sediment pos-

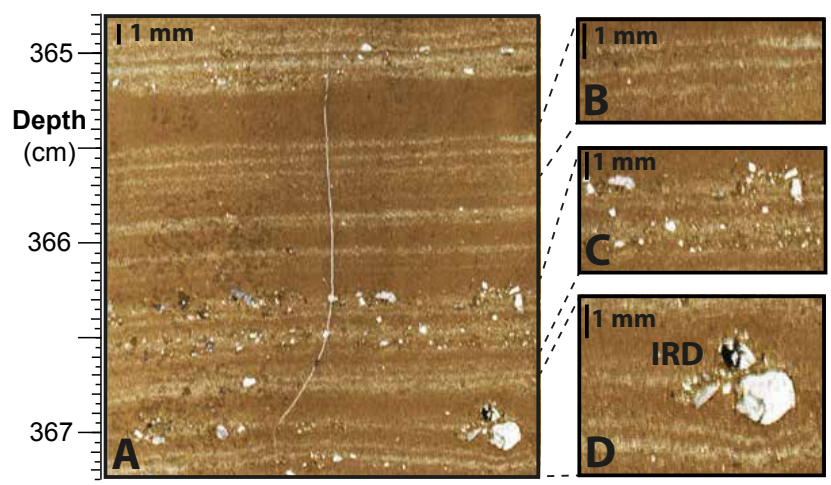

Figure 3. Detailed images of a scanned thin section of PS1795. (A) gives an overview of the varved sediment and the thickness variation of lighter, coarser-grained and darker, finer-grained layers. On the right are three close-up photos: typical varves (B); sandrich lighter coarser-grained layers with some ice-rafted debris (IRD) (C); (D) shows some individual large IRD, deposited by deforming the sediment below.

sibly includes about 260-380 varves, which gives an age for the top of the varved sediments of between 21.8 and $22.4 \mathrm{ka}$. The topmost $2.15 \mathrm{~m}$, cover about the last $17-18 \mathrm{kyr}$ as the ${ }^{14} \mathrm{C}$ age of $17.44 \pm 0.36 \mathrm{ka}$ close to the base of the bioturbated section reveals. This reflects LSR of only $0.12 \mathrm{~m} \mathrm{kyr}^{-1}$ for the bioturbated sediment. Accordingly, the combination of varve counting and radiocarbon dating strongly suggests incomplete sedimentation, with a hiatus of approximately 3 to 4 kyr (Fig. 2). Therefore we use the age model that incorporates the hiatus.

\subsection{Varves}

The varve character of the laminations has been established in earlier studies (Weber et al., 1994, 2010, 2011). The most convincing argument is provided by core PS1789 (location see Fig. 1), which yields the visually most complete record of LGM varvation. Two horizons at 199 and $1211 \mathrm{~cm}$ core depth date to 19.223 and $22.476 \mathrm{ka}$, respectively. Over this age difference of 3253 years ( \pm 529 years), we counted 3329 laminae couplets (see Fig. 8 of Weber et al., 2010) - a very convincing and robust indication of the seasonal nature of the lamination. The ${ }^{14} \mathrm{C}$ ages and varve counting results of PS1795 of this study also confirm the seasonal sedimentation (see below).

In this study, analyses concentrate on laminated sections of newly opened core PS1795. Accordingly, the density of the coarser-grained layers is slightly higher, leading to less darkening of the X-ray film (Axelsson, 1983). Therefore, Xradiographs have been successfully used for varve counting on sediment cores PS1599, PS1789, and PS1791 (Weber et al., 2010). Although the varved sections of PS1795 have similar average grain sizes as the cores studied previously, the seasonal differences are subdued, the X-radiographs do not 


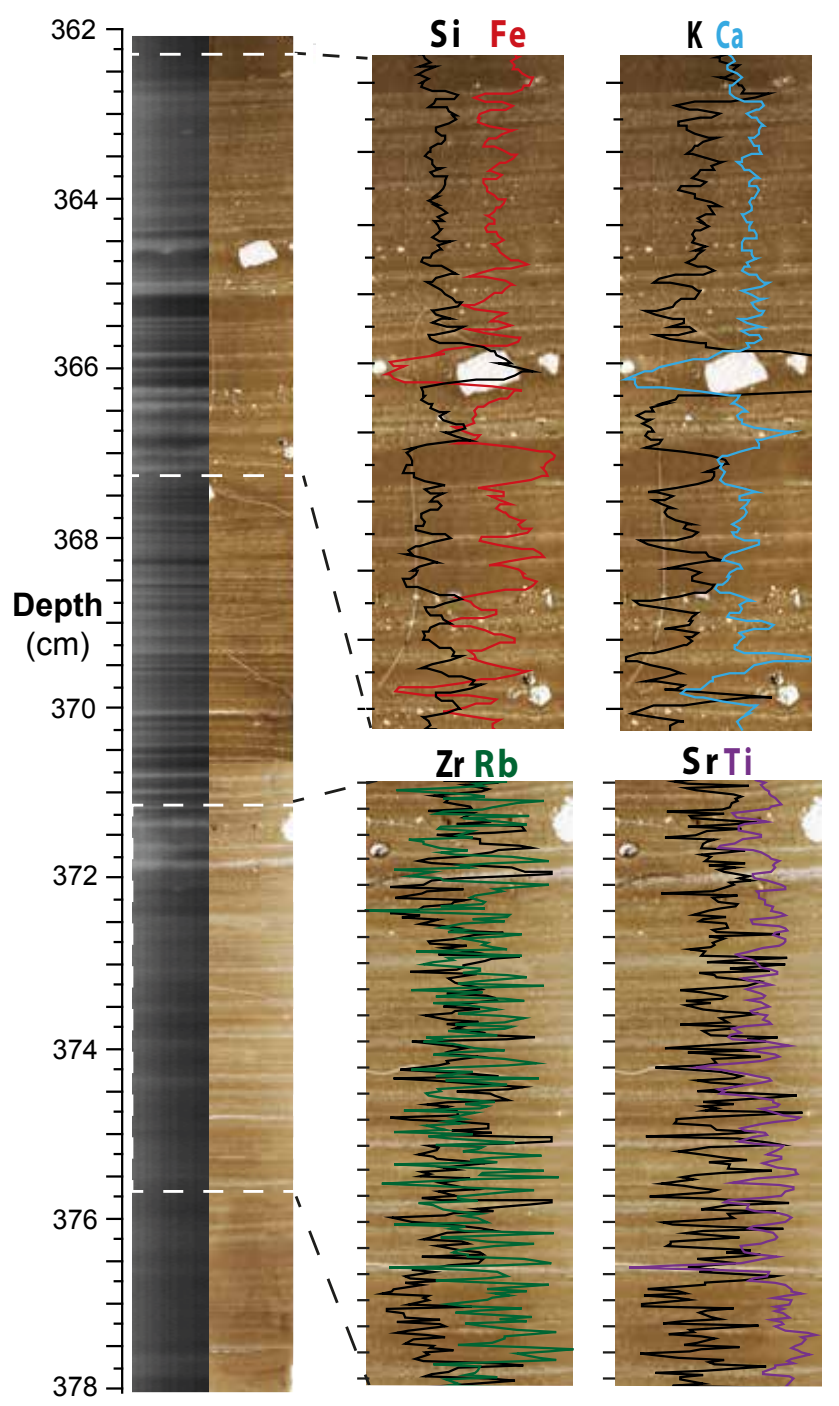

Figure 4. High-resolution element composition of a varved sediment section of core PS1795 $(362-378 \mathrm{~cm})$. Left: X-radiographs, generated using X-ray fluorescence (XRF) scanner and scanned images of the thin sections. Right: close-up images of thin sections plus XRF scanner element counts every $0.2 \mathrm{~mm}$ of the sediment slabs, from which the thin sections were produced.

show the differences accordingly (Fig. 4) and the layers cannot always be adequately counted. To obtain more information on the texture and composition of the individual layers as well as to obtain a better understanding of the seasonal sedimentation process, we produced thin sections of the varved sediment.

\subsubsection{Thin sections}

Figures 3 and 4 show that the scanned images of the thin sections provide more detailed information of the internal structure and composition of the varves. Strong thickness variations can be noticed both in the darker, finer-grained

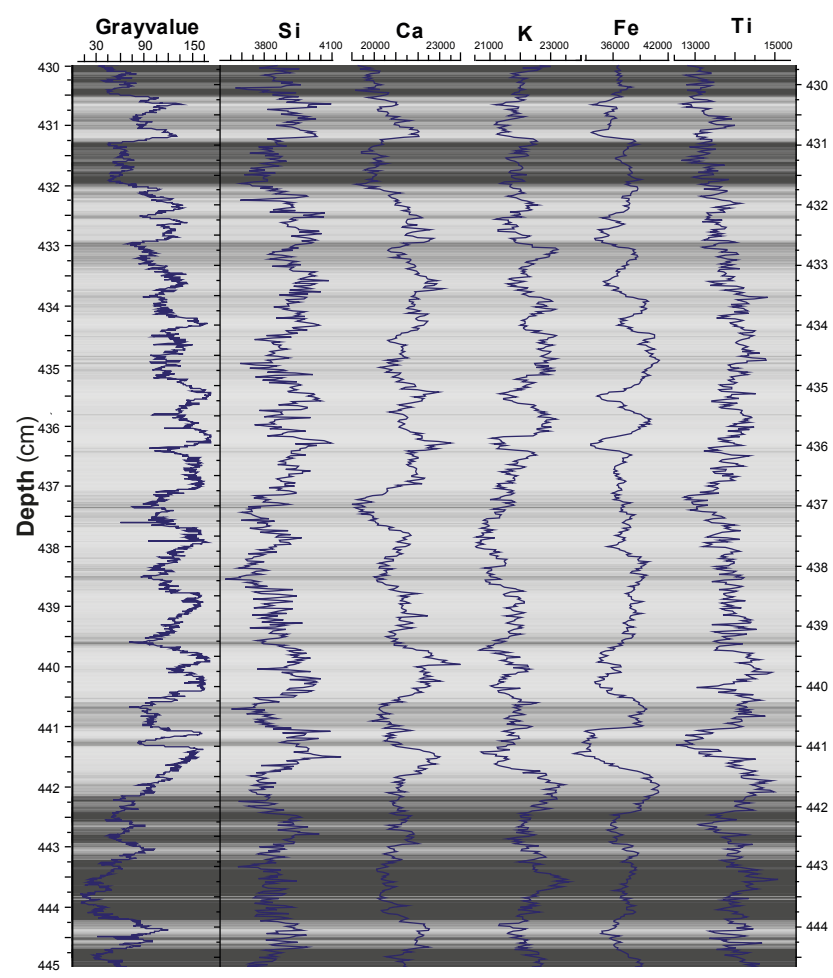

Figure 5. Seasonal-scale changes in chemical element composition: high-resolution X-ray fluorescence scanner data (area counts) every $0.2 \mathrm{~mm}$ of PS1795 core section $(430-445 \mathrm{~cm})$. Additionally, the estimated grey scale value curve estimated from scanned Xradiograph using the BMPix tool (Weber et al., 2010) was added.

layers and the lighter, coarser-grained layers (Fig. 3), with thicknesses of only few $100 \mu \mathrm{m}$ up to $3 \mathrm{~mm}$. The darker, finer-grained layers are often thicker than the lighter, coarsergrained layers, although the overall thickness variations of both appear to be related to each other, which was also noticed in varved sediment cores PS1599, PS1789, and PS1791 (Sprenk, unpublished data).

There are only small variations in grain size and no erosional or sharp bases. Both findings argue against turbiditic deposition and favour varve formation (Fig. 3a). Sand and coarse-silt contents may vary significantly between individual layers. However, some parts of the record reveal very little difference in grain size so that individual layers are hardly recognizable in thin sections (Fig. 3) and cannot be distinguished on X-radiographs (Fig. 4) at all. Some layers are completely IRD-free (Fig. 3b), while others contain high amounts of sand-size grains (Fig. 3c). In some lighter, coarser-grained layers the amount of IRD seems to be higher, although a striking relation between the seasonal deposits and the counted IRD is not noticeable. Figure $3 d$ shows some large IRD - up to $2 \mathrm{~mm}$ in diameter - deforming the underlying layers. This is a clear indication that either icebergs or sea ice transported the IRD and deposited it by dropping onto the sea floor. 
Table 2. Characteristics of seasonally deposited darker, finergrained layers and lighter, coarser-grained layers. Elements were measured using an ITRAX X-ray fluorescence scanner (see also Figs. 4-6).

\begin{tabular}{lrr}
\hline Characteristics & $\begin{array}{r}\text { Darker, finer- } \\
\text { grained layers }\end{array}$ & $\begin{array}{r}\text { Lighter, coarser- } \\
\text { grained layers }\end{array}$ \\
\hline Colour & brown & light-coloured \\
$\mathrm{Si}, \mathrm{Ca}, \mathrm{Sr}, \mathrm{Zr}$ & low & high \\
$\mathrm{K}, \mathrm{Ti}, \mathrm{Fe}, \mathrm{Rb}$ & high & low \\
Grey value & low & high \\
Silt-sized bright particles & low & high \\
Silt/fine sand content & low & high \\
Ice-rafted debris & low & high \\
\hline Bottom current velocity & low & high \\
\hline
\end{tabular}

\subsubsection{Element composition}

Generally, Fig. 5 shows a good correlation between XRFderived elemental counts and the grey value curve estimated from $\mathrm{X}$-radiographs that mainly reflects density changes of the material. The most important variability of elements in varved sediment are displayed in Figs. 4 and 5 and described in the following sections. Characteristics of the lighter, coarser- and darker, finer-grained layers are also highlighted in Table 2.

Si can either be of detrital or biogenic origin, i.e. bounded in biogenic opal (Sprenk et al., 2013). Given that the biogenic opal content of the glacially deposited varves (Fig. 2k; Sect. 4.1) of PS1795 is less than 5\%, with a mean of $2.2 \%$, $\mathrm{Si}$ should mostly be of detrital origin. Analyses of the coarsegrained fraction also revealed that, on average, about $80 \%$ of the particles coarser than $63 \mu \mathrm{m}$ are actually quartz grains. The combination of thin sections and XRF data (Fig. 4) highlights that $\mathrm{Si}$ counts are relatively enriched in lighter, coarsergrained layers relative to darker, finer-grained layers. This indicates that Si counts every $0.2 \mathrm{~mm}$ can be an ideal additional tool for detrital varve counting. Figure 5 shows that the overall amount of $\mathrm{Si}$ also correlates to grey values derived from radiographs, which are positively correlated to sediment density (see Sect. 3). Si counts are also a good indicator for facies changes (see Fig. 2) with significantly lower values in bioturbated sections relative to varved sections, due to increased water content of the sediment.

Potassium $(\mathrm{K})$, iron $(\mathrm{Fe})$ and titanium $(\mathrm{Ti})$ show strong positive correlation, which is reflected in the $\mathrm{Ti} / \mathrm{Fe}$ ratio of $r^{2}=0.84$ and $\mathrm{K} / \mathrm{Ti}$ ratio of $r^{2}=0.90$. This suggests that $\mathrm{K}$, $\mathrm{Fe}$ and $\mathrm{Ti}$ are mainly bound in clay minerals from the chlorite and illite groups as well as in mica biotite. Figure 4 highlights that $\mathrm{K}, \mathrm{Fe}$ and $\mathrm{Ti}$ show maxima in the darker, finer-grained layers. Rubidium $(\mathrm{Rb})$ has a similar ionic radius as $\mathrm{K}$. Therefore, it commonly replaces it and can often be detected in Kfeldspars, mica and clay minerals (Chang et al., 2013). Cu,

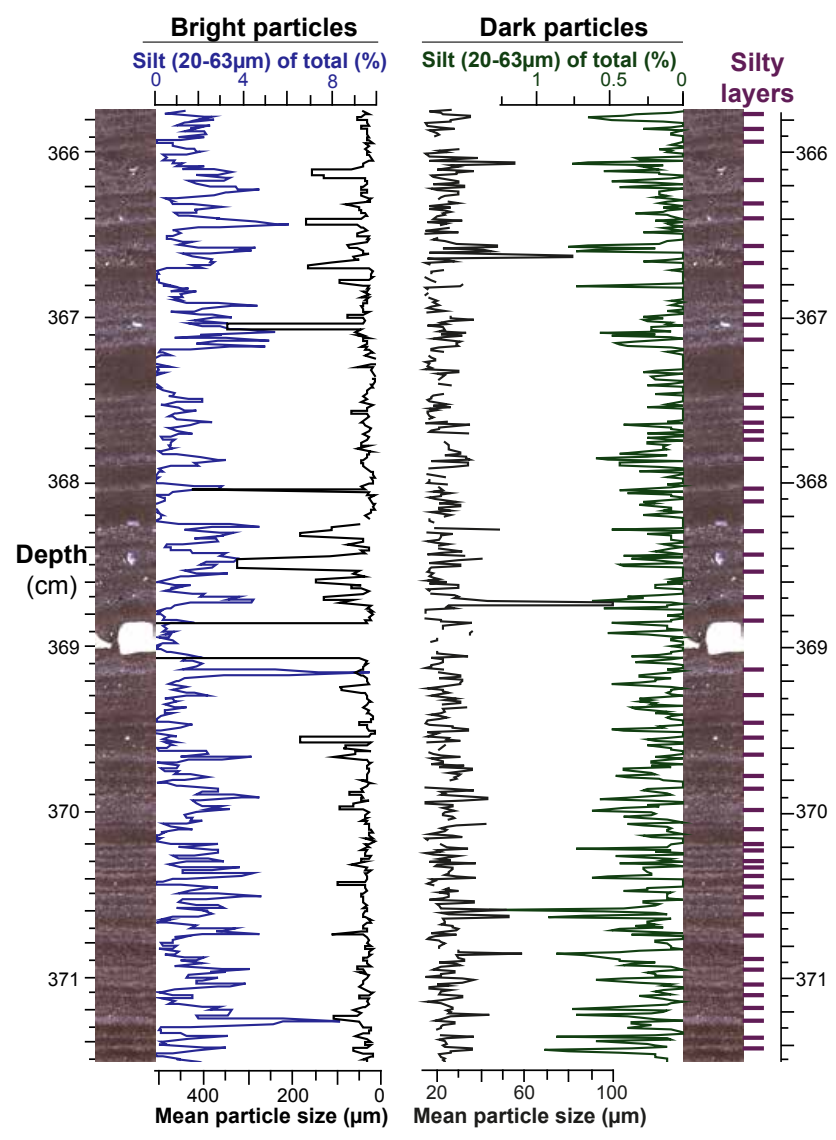

Figure 6. Detailed particle analysis of the varved sediment section $365.8-371.5 \mathrm{~cm}$ with the RADIUS tool (Seelos and Sirocko, 2005) applied on high-resolution scans of the thin sections. The $20-63 \mu \mathrm{m}$ fraction refers to medium to coarse silt. Total refers to all analysed particle classes from 20 to $200 \mu \mathrm{m}$ in grain size. Purple bars mark the 52 counted lighter coarser-grained layers leading to a linear sedimentation rate of about $1.1 \mathrm{~m} \mathrm{kyr}^{-1}$.

$\mathrm{Zn}, \mathrm{Rb}, \mathrm{Cs}, \mathrm{Ba}$ and $\mathrm{Sn}$ are generally related to clay minerals (Vital and Stattegger, 2000). Fine-grained sediments typically show high Rb counts (Dypvik and Harris, 2001), which is also documented in varved sections of PS1795, where $\mathrm{Rb}$ similar to $\mathrm{K}, \mathrm{Fe}$, and $\mathrm{Ti}$ is enriched in the darker, finer-grained layers (Fig. 4). Strontium (Sr) has an atomic radius similar to calcium $(\mathrm{Ca})$ and can therefore replace it easily. Both elements are slightly enriched in the lighter, coarser-grained layers (Fig. 4). Ca and Si show a good correlation with a coefficient of $r^{2}=0.78$. Zirconium ( $\mathrm{Zr}$ ) is comparatively immobile, mainly residing in heavy minerals, e.g. zircon, resistant to chemical as well as physical weathering (Wayne Nesbitt and Markovics, 1997; Alfonso et al., 2006). Thus $\mathrm{Zr}$ is mainly transported with coarser particles (Vogel et al., 2010). $\mathrm{Zr}$ shows maxima mainly in the lighter, coarser-grained layers, especially in the thicker layers (Fig. 4). 


\subsubsection{RADIUS tool}

To gain more information on the particles and their size distribution in varved layers, we applied the particle analysing RADIUS tool (Seelos, 2004) on high-resolution, scanned thin sections. The RADIUS tool differentiates between (i) bright particles, i.e. mainly quartz, and light feldspars, (ii) dark particles, i.e. opaque minerals, and (iii) carbonates (Seelos and Sirocko, 2005). Carbonate particles are neglected in Fig. 6 given that the values are extremely low and not significant, which is also reflected in the low TIC content of varved sediment (Fig. 2).

Figure 6 shows the percentage of detected bright and dark particles in the grain size fraction $20-63 \mu \mathrm{m}$, i.e. medium to coarse silt, of total grains (i.e. of all classified grains up to $200 \mu \mathrm{m}$ in diameter). In lighter, coarser-grained layers, bright silt-sized particles have local maxima and are accounting for up to $10 \%$ of the total grains. Also, the mean size of the bright particles is mostly higher in lighter, coarser-grained layers than in darker, finer-grained layers (Fig. 6), although single IRD, e.g. at 365.5 or $369 \mathrm{~cm}$, may strongly influence the mean particle size. The median size of bright particles is about $34 \mu \mathrm{m}$. In contrast, dark particles have only median sizes of about $22 \mu \mathrm{m}$. This is also reflected in the overall low content of dark particles in the medium to coarse silt fraction with $0-1.2 \%$ of all classified grains. The correlation of the silt-sized, dark particles and the sediment layers is not as striking as for the bright particles (Fig. 6). However, many lighter, coarse-grained layers also show increased amounts in silt-sized as well as higher mean size of dark particles.

\section{Discussion}

\subsection{Seasonal sedimentation changes}

Our age model relying on ${ }^{14} \mathrm{C}$ dates and varve counting reveals that the varved sections underneath the bioturbated top of core PS1795 were deposited during the LGM. This is in agreement with results for other sediment cores from the same channel-ridge system (Weber et al., 2011) and provides further indication that the ice sheet in the southeastern Weddell Sea had advanced to the shelf break (e.g. Weber et al., 2011; Hillenbrand et al., 2012). The estimated linear sedimentation rate of about $1.1-1.6 \mathrm{~m} \mathrm{kyr}^{-1}$ for the varved sediment of PS1795 (e.g. Fig. 6) is somewhat lower than established for core sites farther downslope on the same channel-ridge system. Mean linear sedimentation rates from varve counting varying between 2.2 and $5.3 \mathrm{~m} \mathrm{kyr}^{-1}$ (Sprenk, unpublished data) were calculated for the cores PS1599, PS1789 and PS1791 (Fig. 1). The differences are likely related to the location of the core sites with PS1795 originating from a shallower position farther southwest outside of the channel, on a steeper part of the continental slope (Fig. 1), where the channel-ridge system starts to develop.
Detailed grain size investigation (see Figs. 10 and 13 of Weber et al., 1994) showed that, although not conducted on specific laminae, higher silt content of sediment deposited during the LGM also revealed better sorting coefficients and more negative skewness of the silt, which is a clear indication of current transport, thus suggesting that most of the silt fraction was transported and delivered by the thermoline current to the core site and not by IRD, as the IRD delivery of the silt fraction would yield a wide range of unsorted grain sizes. During the recent Interglacial, when the ice sheet is retreated from the shelf edge and sea ice is reduced, the velocity of the thermohaline current in the channels is then strongly decreased or even inactive. This leads to significantly reduced accumulation rates on the ridges and the deposition of unsorted bioturbated, hemipelagic mud sometimes including IRD (Fig. 2). Due to the closeness of the sediment cores to the IRD source, e.g. leading to noise, it is not really possible to make a prediction of a possible connection between the sedimentation and the IRD.

As the sediment core PS1795 originates from $1884 \mathrm{~m}$ water depth in the SE Weddell Sea, it is not located in the bioproductivity zone. Overall, bioturbated sediment shows higher TOC, TIC, TN, and biogenic opal values than varved sediment (Fig. 2), indicating higher bioproductivity during the recent Interglacial than during the LGM. Investigations showed that the varved sediment deposited during the LGM consists mainly of detrital material, which is transported by thermohaline currents down the continental slope and only 2-6\% biogenic opal. Biogenic opal and organic carbon data were measured every $5 \mathrm{~cm}$, therefore the resolution is too low to investigate seasonal changes and we do not have any information about seasonal biogenic opal changes during the LGM in the core site area. Analyses of the coarse-grained fraction $(>63 \mu \mathrm{m})$ also revealed that, on average, about $80 \%$ of the particles coarser than $63 \mu \mathrm{m}$ are actually quartz grains. The combination of thin sections and XRF scanner Si counts obtained every $0.2 \mathrm{~mm}$ highlights that $\mathrm{Si}$ counts are relatively enriched in the lighter, coarser-grained layers relative to the darker, finer-grained layers (see Sect. 4.3.2).

The main differences of the layers deposited during the LGM come from seasonal changes in grain size and related changes in element and mineral composition (Table 2), leading to overall varved sediment. Lighter, coarser-grained layers show maxima in the amount of bright particles, mainly quartz in the medium-to-coarse silt grain size (Fig. 6), which is also reflected in Si count maxima (Figs. 4, 5). Lighter, coarser-grained layers also show slightly increased amounts of silt-sized dark particles and higher $\mathrm{Zr}$ counts. In addition, the lower darkening of the X-ray film (Fig. 4) indicates higher densities. Darker, finer-grained layers are characterized by predominantly finer-grained particles, higher amounts of mica, clay minerals (from chlorite and illite group members).

The finer-grained particles should also originate, to a certain extent, from the bottom nepheloid layer, a layer of 
variable thickness and rich in suspended material directly above the ocean floor (McCave, 1986). The overspilling thermohaline current should deliver a wider range of fine particles. From this size fraction, the coarser part should settle first and closer to the channel, whereas the finer part can stay in suspension in the bottom nepheloid layer and may deposit later.

\subsection{Modern and LGM polynyas and their relation to bottom-water production in the Weddell Sea}

Today, Antarctic coastal polynyas are very important areas for $\mathrm{AABW}$ production and therefore also contribute to the overturning circulation in the oceans (Morales Maqueda et al., 2004). Offshore blowing katabatic winds remove sea ice from coastal areas or the shelf-ice edge and often lead the development of coastal polynyas (Williams et al., 2007; Kern, 2009). When these spaces of open water areas are formed, oceanic heat can be released to the atmosphere. When atmospheric temperatures are very low, sea-ice production will be intensified, leading to brine rejection and thus dense water formation in the ocean (Tamura et al., 2008). Haid and Timmermann (2013) identified the Brunt Ice Shelf, which is close to the core sites (Fig. 1), together with the Rønne Ice Shelf (e.g. Hollands et al., 2013) and southern regions of Antarctic Peninsula as important polynya areas and highlighted that ice production is 9-14 times higher in these areas compared to neighbouring regions with the highest mean heat flux during the winter months July and August. Today, coastal polynyas are pervasive around Antarctica during winter (Kern, 2009) and considered as the areas of highest ice production in winter (Morales Maqueda et al., 2004). Tamura et al. (2008) estimated that $10 \%$ of all sea ice in the Southern Ocean and about $6 \%$ in the Weddell Sea (Renfrew et al., 2002) is produced in Antarctic coastal polynyas. In the Weddell Sea, investigations showed that years with large coastal polynya areas are in accordance with maxima in total ice extent (Comiso and Gordon, 1998). Renfrew et al. (2002) highlighted that the inter-annual variations in coastal polynya activity and area seem to be related to katabatic winds, cyclones, and barrier winds. Markus et al. (1998) showed that today in spring and summer the polynya size in the Weddell Sea reduces, due to a combination of ice convergence against the peninsula and a weakening of the offshore, e.g. katabatic winds.

Heinemann et al. (2013) studied coastal polynyas in the Weddell Sea area and showed that in the area of Coats Land, in front of the Brunt Ice Shelf, which is close to core site PS1795 (Fig. 1), the offshore winds are mainly driven by katabatic winds, due to the steepness and length of the slope. However, for glacial conditions, there is still little knowledge on katabatic winds and coastal polynya activity as well as their seasonal changes in the southeastern Weddell Sea. Due to the fact that ice sheets covered the continental shelf in the Weddell Sea during the LGM (Weber et al., 2011), the bottom-water formation must have deviated from today, where dense bottom waters are formed on the continental shelf underneath the ice shelves (e.g. Haid and Timmermann, 2013).

Upwelling of warm deep water can also generate polynyas due to preventing of sea-ice formation or enhancing of seaice melting (Smith et al., 1990), which are called sensible heat polynyas. However, Antarctic polynyas mainly occur on the continental shelves as well as close to the coasts (Massom et al., 1998) and are latent-heat polynyas, driven by wind force (Barber and Massom, 2007), e.g. katabatic winds. Recently, there is strong evidence that during deglaciation and recent times, Antarctic-wide upwelling of WDW is a key element in destabilizing ice sheets and ice shelves (e.g. Rignot and Jacobs, 2002; Weber et al., 2011; Jacobs et al., 2011), as well as overall reduction in sea ice. During the LGM, however, sea ice extended far north and the Weddell Gyre was likely more sluggish, as also indicated by modelling studies (Lohmann, personal communication, August 2013). Therefore, it seems highly unlikely that large volumes of Warm Deep Water could have entered the Weddell Sea from the northeast through the Weddell Gyre and contributed to extensive polynya formation during the LGM, specifically not in a seasonal fashion (Weber et al., 2011).

LGM simulations by Shin et al. (2003) showed that around $80 \%$ of the AABW could have been formed by increased brine release in the sea-ice production zones in the Southern Ocean. Coastal polynyas in front of the grounded ice sheet above the continental slope might have played a major role in the bottom-water formation during the LGM. Earlier studies (e.g. Weber et al., 1994, 2011) indicated that during the LGM intensified katabatic winds likely drove coastal polynya formation in the southeastern Weddell Sea with declining coastal polynya intensity away from the coast and the strongest effect in front of the ice sheet and ice shelf and coastal areas. Smith et al. (2010) also pointed out that during the last glacial, off-blowing katabatic winds in front of the grounded Antarctica Peninsula Ice Sheet formed coastal polynyas in the western Weddell Sea.

The Weddell Sea varves were deposited only during glacial times when the grounded ice sheet had very likely advanced to the shelf break (e.g. Hillenbrand et al., 2012). Based on earlier work (e.g. Kuhn and Weber, 1993; Weber et al., 1994) as well as on this study, we favour the following scenario of glacial sedimentation: during the LGM, plumes of cold and dense water were generated in front of the grounded East Antarctic Ice Sheet above the upper slope by coastal polynyas, i.e. strong offshore blowing (i.e. katabatic) winds enhanced sea-ice formation and thus formed brine release. The resulting dense water mass moved down the continental slope and was canalized into the channelridge systems northeast of Crary Fan (Fig. 1), producing cold and saline WSBW. Apparently, this flow oscillated seasonally with a stronger salt injection during glacial winter due to increased brine release by more intense coastal polynyas. 
We should note that spaces of open water, which were generated by the katabatic winds and led to glacial polynyas, did likely not stay open for long because of the low temperatures or it might also represent a region with a very thin ice-cover and no open water at all (Renfrew et al., 2002). Rapid freezing and associated intense brine rejection should therefore be a major difference to present-day polynyas, which may stay open for longer and do therefore not invoke major brine rejection. The resulting glacial thermohaline current flowed underneath and against the probably weakened Weddell Gyre.

During glacial summer, glacial meltwater channels could have also delivered meltwater. That process, however, would only deliver freshwater that is not dense enough to sink down and move across the shelf onto the continental slope and into the channels, which accompany the ridges because the surrounding brines are much denser and colder (Nicholls et al., 2009) than the meltwater. Also, seasonal deposition on the ridges requires a continuous flow of a dense water mass at varying volume (velocity) in the channels. This process should therefore be sustained by a seasonally variable thermohaline convection resulting from polynya formation in front of the ice edge.

Darker, finer-grained layers would hence have be interpreted as a signal of a less windy season, possibly summer, resulting from less intense katabatic winds, hence less seaice transport away from the coast, and reduced brine rejection in front of the ice sheet that led to reduced thermohaline convection, lower current velocities in the channels, and less overspilling on the ridges.

Lighter, coarser-grained layers likely represent a signal of a windier glacial season, mainly winter, as a result of enhanced katabatic winds that carried sea ice away from the continent more effectively, inducing rapid freezing processes at the surface that spurred thermohaline convection and led to higher velocities in the channels and higher overspilling on the ridges. As a whole, the seasonally variable thermohaline convection produced large volumes of bottom water and transported vast amounts of sediment into the deeper environment that have originally been delivered by meltwater channels from the grounded ice sheet and/or by gravitational processes (Anderson et al., 1986), leaving its trace in the form of varved sediment on the ridges (Figs. 3-5). In a coupled climate model, Justino and Peltier (2006) demonstrated that the seasonal cycle in the Southern Ocean was likely much stronger during the LGM than it is today with a very pronounced winter season.

\section{Conclusions}

We presented high-resolution sediment physical and geochemical data of the newly opened sediment core PS1795 from a channel-ridge system located on a terrace of the continental slope of the southeastern Weddell Sea. ${ }^{14} \mathrm{C}$ ages and varve counting results for PS1795 support earlier studies and indicate that laminations represent true varves and are therefore seasonally deposited during the LGM with sedimentation rates of about $1.1-1.6 \mathrm{~m} \mathrm{kyr}^{-1}$. Thin sections, XRF scanning at $0.2 \mathrm{~mm}$ resolution, as well as RADIUS tool analysis reveal detailed information of the internal varve composition. Individual layers have thicknesses of only a few hundred $\mu \mathrm{m}$ up to $3 \mathrm{~mm}$. The facts that laminae couplets show only small variations in grain size and that there are no erosional or sharp surfaces, argue against turbiditic sedimentation and favour varve formation. In fact, grain-size variability of some parts is so low that layers are hardly distinguishable in thin sections and cannot be recognized on X-radiographs at all. Analyses of thin sections show that IRD is mainly embedded in the lighter, coarser-grained layers with some large debris - up to $2 \mathrm{~mm}$ in diameter - deforming the underlying layers. This is a clear indication of transport by either icebergs or sea ice, and deposition by dropping onto the sea floor.

Our results reveal seasonal changes in grain size and related changes in element and mineral composition. Lighter, coarser-grained layers contain higher amounts of silt-sized particles, mostly quartz grains, which is also shown by maxima in Si counts. Additionally, the lighter coarser-grained layers are also enriched in $\mathrm{Zr}$, reveal coarser grain sizes, and show higher densities as indicated by less darkening of the $\mathrm{X}$-ray film. Darker, finer-grained layers contain mainly claysized particles as well as maxima in $\mathrm{K}, \mathrm{Fe}$, Ti and $\mathrm{Rb}$, i.e. typical trace elements for clay minerals such as chlorite and illite as well as mica (biotite).

Consequently, sedimentation in the channel-ridge system was highly dynamic during the LGM, reflecting seasonal velocity changes of the thermohaline current that transported sediment from the upper slope downslope to the core sites. Sediments were deposited when the grounded ice sheet had advanced to the Weddell Sea shelf edge. Offshore blowing (katabatic) winds removed sea ice from the ice edge and coastal polynyas developed. We suggest that glacial coastal polynya processes were in general similar to today inasmuch as stronger katabatic winds and enhanced coastal polynya activity occurred during the winter season. However, that does not necessarily imply that spaces of open water may have existed for long. Following this concept, lighter, coarsergrained layers are likely glacial deposits of a windy season, mainly winter, when brine release was increased, leading to intensified bottom-water formation and increased sediment transport. Vice versa, darker, finer-grained layers were deposited during the less windy season, mainly summer, when coastal polynya activity was reduced. 
Acknowledgements. The authors are grateful for financial support from the Deutsche Forschungsgemeinschaft (DFG; grants RI 525/17-1, KU 683/9-1, WE2039/8-1) and the DFG-Priority Programme Antarctic Research 1158. Our study was part of the Alfred Wegener Institute research program "Polar Regions and Coasts in a changing Earth System" (PACES), Topic 3 "Lessons from the Past". We thank Irka Hajdas from the Laboratory of Ion Beam at the ETH Zurich for the AMS ${ }^{14} \mathrm{C}$ measurements as well as Ralf Baeumler and Jens Karls from the University of Cologne for helping with the thin sections. All data will be available at http://doi.pangaea.de/10.1594/PANGAEA.833377.

Edited by: A. Elmore

\section{References}

Alfonso, J. A., Martínez, M., Flores, S., and Benzo, Z.: Distribution of Trace Elements in Offshore Sediments of the Orinoco Delta, J. Coast. Res., 22, 502-510, doi:10.2112/03-0142.1, 2006.

Anderson, J. B., Wright, R., and Andrews, B.: Weddell Fan and Associated Abyssal Plain, Antarctica: Morphology, Sediment Processes, and Factors Influencing Sediment Supply, Geo-Mar. Lett., 6, 121-129, 1986.

Axelsson, V.: The use of X-ray radiographic methods in studying sedimentary properties and rates of sediment accumulation, Hydrobiologia, 103, 65-69, 1983.

Barber, D. G. and Massom, R. A.: Chapter 1 The Role of Sea Ice in Arctic and Antarctic Polynyas, in: Elsevier Oceanography Series, edited by: Smith, W. O. and Barber, D. G., Elsevier, 1-54, 2007.

Beckmann, A., Hellmer, H. H., and Timmermann, R.: A numerical model of the Weddell Sea: Large-scale circulation and water mass distribution, J. Geophys. Res.-Oceans, 104, 23375-23391, doi:10.1029/1999JC900194, 1999.

Blaauw, M.: Methods and code for "classical" age-modelling of radiocarbon sequences, Quaternary Geochronol., 5, 512-518, doi:10.1016/j.quageo.2010.01.002, 2010.

Carmack, E. C. and Foster, T. D.: Water masses and circulation in the Weddell Sea, edited by: Dumkar, M. J., 151-165, 1977.

Chang, H., An, Z., Wu, F., Jin, Z., Liu, W., and Song, Y.: A Rb/Sr record of the weathering response to environmental changes in westerly winds across the Tarim Basin in the late Miocene to the early Pleistocene, Palaeogeogr. Palaeocli. Palaeoecol., 386, 364373, doi:10.1016/j.palaeo.2013.06.006, 2013.

Clark, P. U., Dyke, A. S., Shakun, J. D., Carlson, A. E., Clark, J., Wohlfarth, B., Mitrovica, J. X., Hostetler, S. W., and McCabe, A. M.: The Last Glacial Maximum, Science, 325, 710714, doi:10.1126/science.1172873, 2009.

Comiso, J. C. and Gordon, A. L.: Interannual variability in summer sea ice minimum, coastal polynyas and bottom water formation in the Weddell Sea, Antarctic Res. Ser., 74, 293-315, 1998.

Cook, T., Bradley, R., Stoner, J., and Francus, P.: Five thousand years of sediment transfer in a high arctic watershed recorded in annually laminated sediments from Lower Murray Lake, Ellesmere Island, Nunavut, Canada, J. Paleolimnol., 41, 77-94, doi:10.1007/s10933-008-9252-0, 2009.

Croudace, I. W., Rindby, A., and Rothwell, R. G.: ITRAX: description and evaluation of a new multi-function X-ray core scanner, Geological Society, London, Special Publications, 267, 51-63, 2006.
Dypvik, H. and Harris, N. B.: Geochemical facies analysis of fine-grained siliciclastics using $\mathrm{Th} / \mathrm{U}, \mathrm{Zr} / \mathrm{Rb}$ and $(\mathrm{Zr}+\mathrm{Rb}) / \mathrm{Sr}$ ratios, Chem. Geol., 181, 131-146, doi:10.1016/S00092541(01)00278-9, 2001.

Elverhøi, A.: Glacigenic and associated marine sediments in the Weddell Sea, fjords of Spitsbergen and the Barents Sea: A review, Mar. Geol., 57, 53-88, doi:10.1016/0025-3227(84)901956, 1984.

Foldvik, A.: Oceanographic research during Nare-84/85, Filchner Ronne Ice Shelf Progr. Rep. 3, 107-109, 1986.

Foldvik, A., Gammelsrød, T., and Tørresen, T.: Circulation and water masses on the southern Weddell Sea shelf, in: Oceanology of the Antarctic Continental Shelf, Antarct. Res. Ser., AGU, Washington, DC, 5-20, 1985.

Foldvik, A., Gammelsrød, T., Østerhus, S., Fahrbach, E., Rohardt, G., M., S., Nicholls, K. W., Padman, L., and Woodgate, R. A.: Ice shelf water overflow and bottom water formation in the southern Weddell Sea, J. Geophys. Res., 109, C02015, doi:10.1029/2003JC002008, 2004.

Francus, P. and Asikainen, C. A.: Sub-sampling unconsolidated sediments: A solution for the preparation of undistrubed thinsections from clay-rich sediments, J. Paleolimnology, 26, 323326, doi:10.1023/A:1017572602692, 2001.

Gales, J. A., Larter, R. D., Mitchell, N. C., Hillenbrand, C. D., Østerhus, S., and Shoosmith, D. R.: Southern Weddell Sea shelf edge geomorphology: Implications for gully formation by the overflow of high-salinity water, J. Geophys. Res., 117, F04021, doi:10.1029/2012JF002357, 2012.

Gordon, A. L., Huber, B., McKee, D., and Visbeck, M.: A seasonal cycle in the export of bottom water from the Weddell Sea, Nat. Geosci., 3, 551-556, doi:10.1038/NGEO916, 2010.

Grobe, H.: A simple method for the determination of ice-rafted debris in sediment cores, Polarforschung, 57, 123-126, 1987.

Haid, V. and Timmermann, R.: Simulated heat flux and sea ice production at coastal polynyas in the southwestern Weddell Sea, J. Geophys. Res.-Oceans, 118, 2640-2652, doi:10.1002/jgrc.20133, 2013.

Heinemann, G., Ebner, L., Haid, V., and Timmermann, R.: Katabatic winds and polynya dynamics in the Weddell Sea region (Antarctica), EGU General Assembly 2013, Vienna, 2013.

Hillenbrand, C.-D., Melles, M., Kuhn, G., and Larter, R. D.: Marine geological constraints for the grounding-line position of the Antarctic Ice Sheet on the southern Weddell Sea shelf at the Last Glacial Maximum, Quaternary Sci. Rev., 32, 25-47, doi:10.1016/j.quascirev.2011.11.017, 2012.

Hollands, T., Haid, V., Dierking, W., Timmermann, R., and Ebner, L.: Sea ice motion and open water area at the Ronne Polynia, Antarctica: Synthetic aperture radar observations versus model results, J. Geophys. Res.-Oceans, 118, 1940-1954, doi:10.1002/jgrc.20158, 2013.

Huhn, O., Hellmer, H. H., Rhein, M., Rodehacke, C., Roether, W., Schodlok, M. P., and Schroeder, M.: Evidence of deepand bottom-water formation in the western Weddell Sea, DeepSea Res. Part II, 55, 1098-1116, doi:10.1016/j.dsr2.2007.12.015, 2008.

Jacobs, S. S., Jenkins, A., Giulivi, C. F., and Dutrieux, P.: Stronger ocean circulation and increased melting under Pine Island Glacier ice shelf, Nat. Geosci., 4, 519-523, 2011. 
Jansen, J. H. F., Van der Gaast, S. J., Koster, B., and Vaars, A. J.: CORTEX, a shipboard XRF-scanner for element analyses in split sediment cores, Mar. Geol., 151, 143-153, doi:10.1016/s00253227(98)00074-7, 1998.

Justino, F. and Peltier, W. R.: Influence of present day and glacial surface conditions on the Antarctic Oscillation/Southern Annular Mode, Geophys. Res. Lett., 33, L22702, doi:10.1029/2006GL027001, 2006.

Kern, S.: Wintertime Antarctic coastal polynya area: 1992-2008, Geophys. Res. Lett., 36, L14501, doi:10.1029/2009GL038062, 2009.

Knutti, R., Flückiger, J., Stocker, T. F., and Timmermann, A.: Strong hemispheric coupling of glacial climate through freshwater discharge and ocean circulation, Nature, 430, 851-856, 2004.

Kuhn, G. and Weber, M. E.: Acoustical characterization of sediments by Parasound and $3.5 \mathrm{kHz}$ systems: Related sedimentary processes on the southeastern Weddell Sea continental slope, Antarctica, Mar. Geol., 113, 201-217, 1993.

Larter, R. D., Graham, A. G. C., Hillenbrand, C.-D., Smith, J. A., and Gales, J. A.: Late Quaternary grounded ice extent in the Filchner Trough, Weddell Sea, Antarctica: new marine geophysical evidence, Quaternary Sci. Rev., 53, 111-122, doi:10.1016/j.quascirev.2012.08.006, 2012.

Maldonado, A., Barnolas, A., Bohoyo, F., Escutia, C., GalindoZaldí var, J., Hernández-Molina, J., Jabaloy, A., Lobo, F. J., Nelson, C. H., Rodríguez-Fernández, J., Somoza, L., and Vázquez, J.-T.: Miocene to Recent contourite drifts development in the northern Weddell Sea (Antarctica), Global Planet. Change, 45, 99-129, doi:10.1016/j.gloplacha.2004.09.013, 2005.

Markus, T., Kottmeier, C., and Fahrbach, E.: Ice formation in coastal polynyas in the Weddell Sea and their impact on oceanic salinity, Antarctic Res. Ser., 74, 273-292, 1998.

Massom, R. A., Harris, P. T., Michael, K. J., and Potter, M. J.: The distribution and formative processes of latent-heat polynyas in East Antarctica, Ann. Glaciol., 27, 420-426, 1998.

McCave, I. N.: Local and global aspects of the bottom nepheloid layers in the world ocean, Netherlands J. Sea Res., 20, 167-181, 1986.

Melles, M.: Paläoglaziologie und Paläozeanographie im Spätquartär am Kontinentalrand des südlichen Weddellmeeres, Antarktis, Ber. Polarforsch., 1991.

Michels, K. H., Kuhn, G., Hillenbrand, C.-D., Diekmann, B., Fütterer, D. K., Grobe, H., and Uenzelmann-Neben, G.: The southern Weddell Sea: combined contourite-turbidite sedimentation at the southeastern margin of the Weddell Gyre, Geol. Soc. Memoirs, 22, 305-323, 2002.

Morales Maqueda, M. A., Willmott, A. J., and Biggs, N. R. T.: Polynya dynamics: A review of observations and modeling, Rev. Geophys., 42, RG1004, doi:10.1029/2002RG000116, 2004.

Müller, P. J. and Schneider, R.: An automated leaching method for the determination of opal in sediments and particulate matter, Deep-Sea Res. I, 40, 425-444, 1993.

Nicholls, K. W., Østerhus, S., Makinson, K., Gammelsrød, T., and Fahrbach, E.: Ice-ocean processes over the continental shelf of the southern Weddell Sea, Antarctica: A review, Rev. Geophys., 47, RG3003, doi:10.1029/2007RG000250, 2009.

Orsi, A. H., Nowlin Jr., W. D., and Whitworth III, T.: On the circulation and stratification of the Weddell Gyre, Deep-Sea Res. I, 40, 169-203, 1993.
Orsi, A. H., Johnson, G. C., and Bullister, J. L.: Circulation, mixing, and production of Antarctic Bottom Water, Prog. Oceanogr., 43, 55-109, doi:10.1016/s0079-6611(99)00004-x, 1999.

Petty, A. A., Feltham, D. L., and Holland, P. R.: Impact of Atmospheric Forcing on Antarctic Continental Shelf Water Masses, J. Phys. Oceanogr., 43, 920-940, doi:10.1175/JPO-D-12-0172.1, 2013.

Rahmstorf, S.: Ocean circulation and climate during the past 120,000 years, Nature, 419, 207-214, 2002.

Reimer, P. J., Baillie, M. G. L., Bard, E., Bayliss, A., Beck, J. W., Blackwell, P. G., Ramsey, C. B., Buck, C. E., Burr, G. S., Edwards, R. L., Friedrich, M., Grootes, P. M., Guilderson, T. P., Hajdas, I., Heaton, T. J., Hogg, A. G., Hughen, K. A., Kaiser, K. F., Kromer, B., McCormac, F. G., Manning, S. W., Reimer, R. W., Richards, D. A., Southon, J. R., Talamo, S., Turney, C. S. M., van der Plicht, J., and Weyhenmeyer, C. E.: IntCal09 and Marine09 Radiocarbon Age Calibration Curves, 0-50,000 Years cal BP, Radiocarbon, 51, 1111-1150, 2009.

Renfrew, I. A., King, J. C., and Markus, T.: Coastal polynyas in the southern Weddell Sea: Variability of the surface energy budget, J. Geophys. Res., 107, C6, doi:10.1029/2000jc000720, 2002.

Richter, T. O., van der Gaast, S., Koster, B., Vaars, A., Gieles, R., de Stigter, H. C., De Haas, H., and van Weering, T. C. E.: The Avaatech XRF Core Scanner: technical description and applications to NE Atlantic sediments, Geological Society, London, Special Publications, 267, 39-50, 2006.

Rignot, E. and Jacobs, S. S.: Rapid Bottom Melting Widespread near Antarctic Ice Sheet Grounding Line, Science, 296, 20202023, 2002.

Seelos, K.: Entwicklung einer numerischen PartikelanalyseMethode auf Basis digitaler Dünnschliffaufnahmen und Anwendung der Routine auf die ELSA-HL2- Kernsequenz 66-41 m, Doktor, Institut für Geowissenschaften, Johannes GutenbergUniversität, Mainz, 1-171, 2004.

Seelos, K. and Sirocko, F.: RADIUS - rapid particle analysis of digital images by ultra-high-resolution scanning of thin sections, Sedimentology, 52, 669-681, 2005.

Seidov, D., Barron, E., and Haupt, B. J.: Meltwater and the global ocean conveyor: northern versus southern connections, Global Planet. Change, 30, 257-270, 2001.

Shin, S.-I., Liu, Z., Otto-Bliesner, B. L., Kutzbach, J. E., and Vavrus, S. J.: Southern Ocean sea-ice control of the glacial North Atlantic thermohaline circulation, Geophys. Res. Lett., 30, 6861-6864, doi:10.1029/2002GL015513, 2003.

Smith, J. A., Hillenbrand, C.-D., Pudsey, C. J., Allen, C. S., and Graham, A. G. C.: The presence of polynyas in the Weddell Sea during the Last Glacial Period with implications for the reconstruction of sea-ice limits and ice sheet history, Earth Planet. Sci. Lett., 296, 287-298, doi:10.1016/j.eps1.2010.05.008, 2010.

Smith, S. D., Muench, R. D., and Pease, C. H.: Polynyas and Leads: An Overview of Physical Processes and Environment, J. Geophys. Res., 95, 9461-9479, 1990.

Sprenk, D., Weber, M. E., Kuhn, G., Rosén, P., Frank, M., MolinaKescher, M., Liebetrau, V., and Röhling, H.-G.: Southern Ocean bioproductivity during the last glacial cycle - new decadal-scale insight from the Scotia Sea, Geological Society, London, Special Publications, 381, 245-261, doi:10.1144/SP381.17, 2013.

Stocker, T. F. and Johnson, S. J.: A minimum thermodynamic model for the bipolar seesaw, Paleoceanography, 18, 1087-1095, 2003. 
Tamura, T., Ohshima, K. I., and Nihashi, S.: Mapping of sea ice production for Antarctic coastal polynyas, Geophys. Res. Lett., 35, L07606, doi:10.1029/2007GL032903, 2008.

Vital, H. and Stattegger, K.: Major and trace elements of stream sediments from the lowermost Amazon River, Chem. Geol., 168, 151-168, doi:10.1016/S0009-2541(00)00191-1, 2000.

Vogel, H., Wagner, B., Zanchetta, G., Sulpizio, R., and Rosén, P.: A paleoclimate record with tephrochronological age control for the last glacial-interglacial cycle from Lake Ohrid, Albania and Macedonia, J. Paleolimnol., 44, 295-310, 2010.

Wayne Nesbitt, H. and Markovics, G.: Weathering of granodioritic crust, long-term storage of elements in weathering profiles, and petrogenesis of siliciclastic sediments, Geochim. Cosmochim. Acta, 61, 1653-1670, doi:10.1016/S0016-7037(97)00031-8, 1997.

Weber, M. E.: Estimation of biogenic carbonate and opal by continuous non-destructive measurements in deep-sea sediments: application to the eastern Equatorial Pacific, Deep-Sea Res., 1, 1955-1975, doi:10.1016/S0967-0637(98)00028-4, 1998.
Weber, M. E., Bonani, G., and Fütterer, K. D.: Sedimentation processes within channel-ridge systems, southeastern Wedell Sea, Antarctica, Paleoceanography, 9, 1027-1048, 1994.

Weber, M. E., Niessen, F., Kuhn, G., and Wiedicke, M.: Calibration and application of marine sedimentary physical properties using a multi-sensor core logger, Mar. Geol., 136, 151-172, doi:10.1016/S0025-3227(96)00071-0, 1997.

Weber, M. E., Reichelt, L., Kuhn, G., Pfeiffer, M., Korff, B., Thurow, J., and Ricken, W.: BMPix and PEAK tools: New methods for automated laminae recognition and counting - Application to glacial varves from Antarctic marine sediment, Geochem. Geophys. Geosyst., 11, 1-18, doi:10.1029/2009GC002611, 2010.

Weber, M. E., Clark, P. U., Ricken, W., Mitrovica, J. X., Hostetler, S. W., and Kuhn, G.: Interhemispheric Ice-Sheet Synchronicity During the Last Glacial Maximum, Science, 334, 1265-1269, doi:10.1126/science.1209299, 2011.

Williams, W. J., Carmack, E. C., and Ingram, R. G.: Chapter 2 Physical Oceanography of Polynyas, in: Elsevier Oceanography Series, edited by: Smith, W. O. and Barber, D. G., Elsevier, 55-85, 2007. 